\title{
Weather Risks in the USA
}

\author{
Wolfgang Kron ${ }^{1}$ \\ ${ }^{1}$ Geo Risks Research, Munich Reinsurance Company, Munich, Germany \\ Correspondence: Wolfgang Kron, Geo Risks Research, Munich Re, Koeniginstrasse 107, Munich 80791, \\ Germany. Tel: 49-89-3891-5260. E-mail: wkron@munichre.com
}

Received: June 18, 2013 Accepted: July 7, 2014 Online Published: July 11, 2014

doi:10.5539/enrr.v4n3p166 URL: http://dx.doi.org/10.5539/enrr.v4n3p166

\begin{abstract}
Weather risks are changing faster in North America than anywhere else in the world. Three components contribute to this risk: hazard, exposure (or values at risk) and vulnerability. While hazards are inherently natural, humans determine where values are placed and how they are protected. Results of the data and scenarios analyzed show that, due to socio-economic factors such as ongoing urbanization and increasing values, the potential for weather-related losses in North America is still rising. In addition, new technologies may give rise to new risks. Natural hazard insurance will therefore remain a challenge, with climate change bringing further uncertainty.

Weather risks resulting from different kinds of windstorms are presented from the viewpoint of a leading reinsurer. Tropical cyclones (hurricanes) are certainly the most devastating weather events in the USA, but a strong upward trend in losses in recent years has made severe thunderstorms almost equally damaging as regards annual aggregated losses; this hazard will also most likely increase further as the climate changes. Extratropical cyclones with significant loss potential can occur year-round; the types of hazard they produce vary greatly by region. Global warming intensifies the risk of severe weather and will result in higher natural peril losses.
\end{abstract}

Keywords: catastrophe losses, climate change, damage, mitigation measures, natural disasters, natural peril insurance, storms, United States, weather risks

\section{Introduction: Natural Catastrophe Statistics}

The USA has been particularly hard hit by weather catastrophes in recent years: hurricanes, tornadoes, floods, wildfires, searing heat and drought. The intensities of certain weather events in North America are among the highest in the world, and the risks associated with them are changing faster than anywhere else (Munich Re, 2012). Hurricane Sandy in October 2012 was but the most recent expression of this development. It came as no surprise, although the wake-up call of Hurricane Irene in 2011 had gone almost unheeded. Now everybody seems to have woken up. But the question is: For how long? Or will it take further events on a comparable scale to force a rethink and trigger more effective action to prepare for extreme weather features? This can only happen if the factors driving the consequences are addressed.

Reinsurer Munich Re has been analyzing natural hazards and the losses they cause for more than 40 years. NatCatSERVICE, the most comprehensive natural catastrophe database worldwide, was set up for this purpose (Wirtz, Kron, Löw, \& Steuer, 2012). The database documents major events from 1950 and all loss-related events from 1980 onwards. Globally, NatCatSERVICE currently comprises more than 34000 data records of individual loss events caused by all types of natural perils (Munich Re, 2013). The number of data records for the USA in the period 1980 to 2012 is 3425 . Of these, some 3200 are weather-related. NatCatSERVICE distinguishes between three event categories relating to the origin of the weather perils:

Meteorological events: Storms (tropical cyclones, extratropical storms, thunderstorms, tornadoes, local storms) and storm-related perils (hail, lightning)

Hydrological events: River floods, flash floods, storm surges and wet mass movements such as landslides or avalanches

Climatological events: Extreme temperatures (heatwaves and cold waves), droughts, wildfires, subsidence and heave

The fourth group is geophysical events (earthquakes, tsunamis, volcanic eruptions and related perils), which is not considered here. 
Most loss-relevant natural events in the USA occur in the eastern half(Figure 1), with storm events in the Midwest, the South, Southeast and Northeast of the USA accounting for the largest share. In the West, heatwaves, droughts, wildfires (and earthquakes) are the dominant hazards. Figure 1 indicates hazard distribution and also gives an approximate idea of the areas in which population and values are located, since those are the areas where hazards can generate losses.

The number of natural catastrophes (of all categories) per year in the USA has clearly been increasing since 1980 (Figure 2), with a roughly fourfold increase from around 40-50 per year in the 1980 s to $160-200+$ per year in recent years. The increase is almost entirely due to the three weather-related categories (meteorological, hydrological and climatological events). This pattern corresponds to the worldwide situation, where a 2.5 -fold increase is observable (from around 400 events in the early 1980 s to about 1000 in recent years).

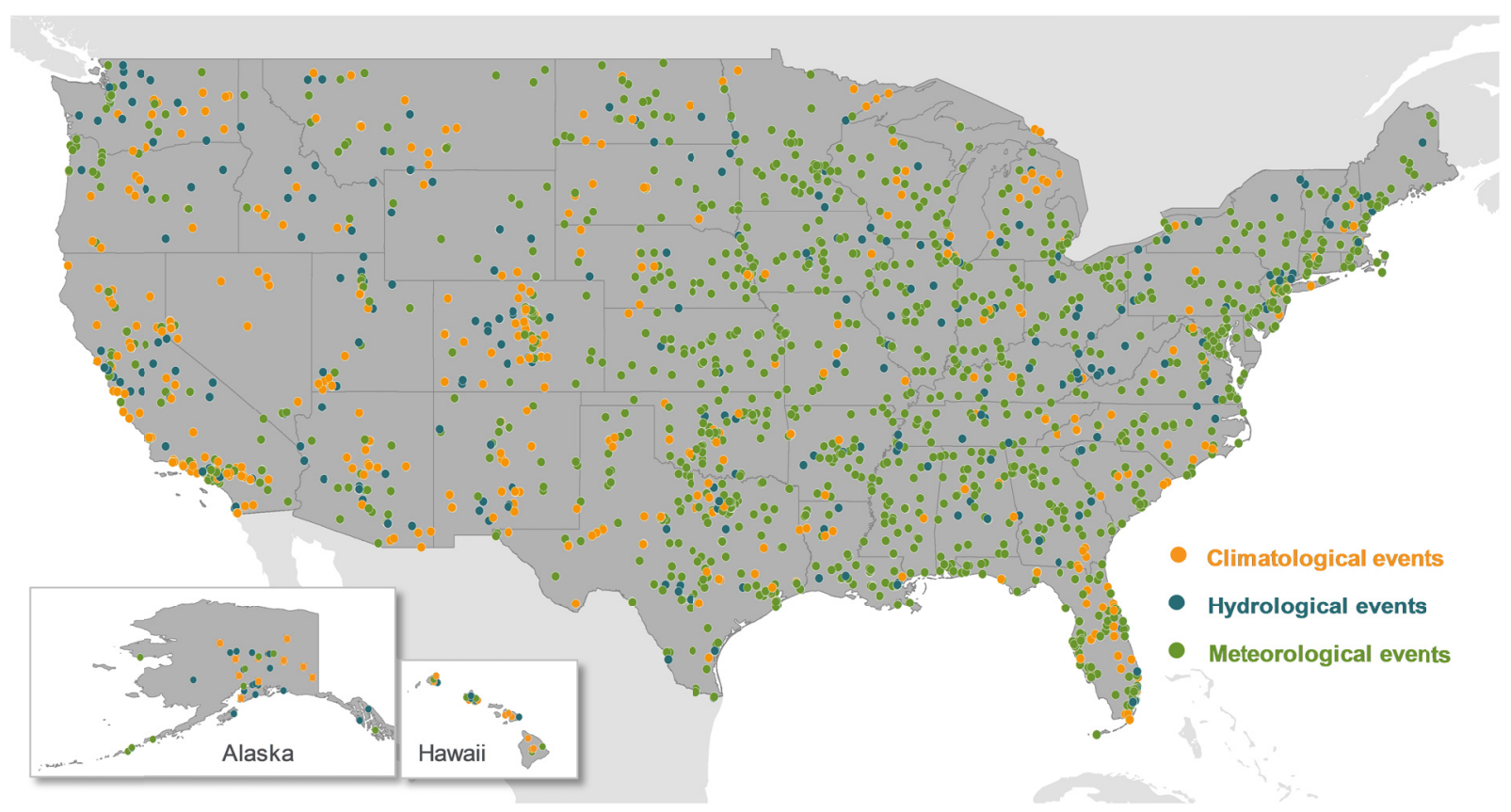

Figure 1. Geographical distribution of weather catastrophes in the USA 1980-2012 (Note: insert maps are not to scale). Source: Munich Re, NatCatSERVICE

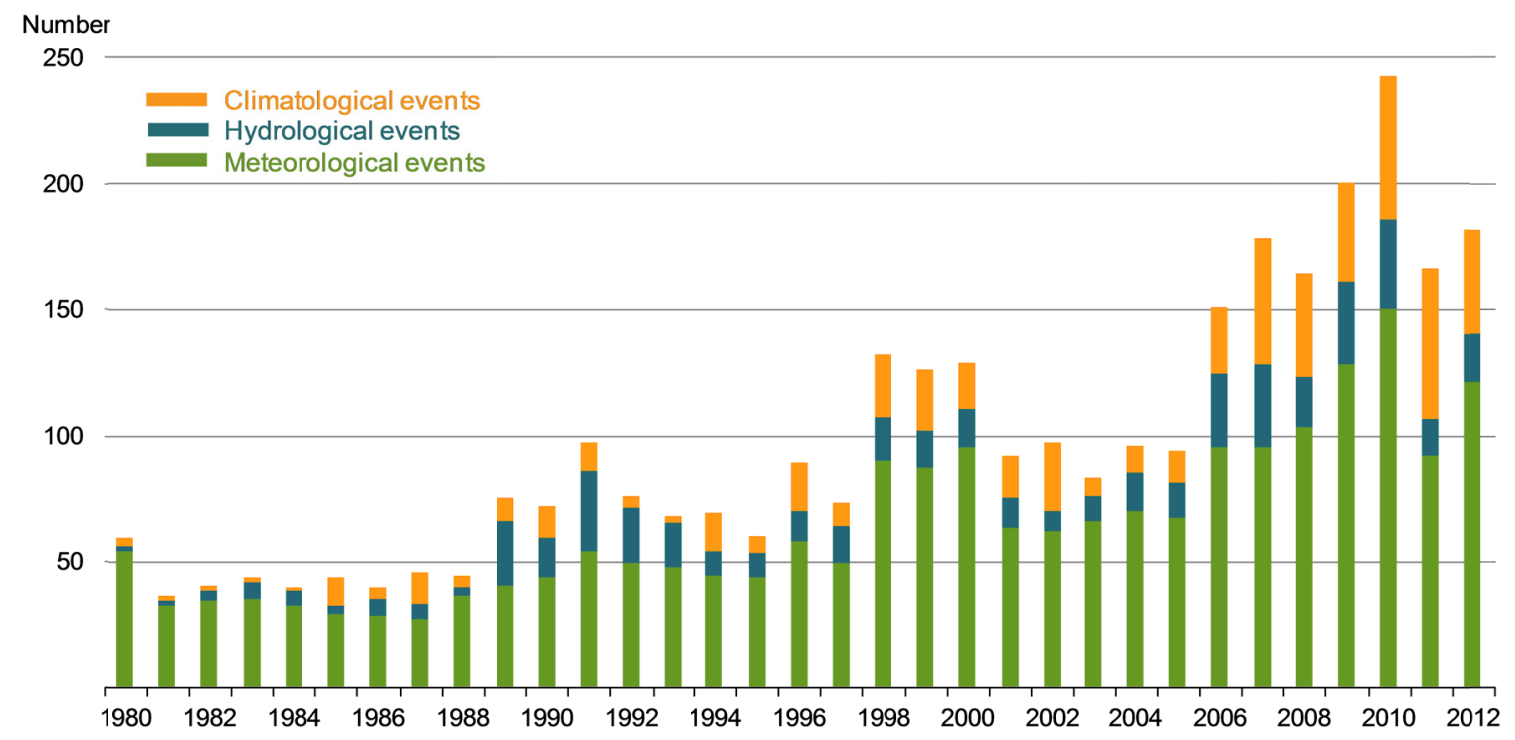

Figure 2. Weather catastrophes in the USA 1980-2012: Number of events. Source: Munich Re, NatCatSERVICE 


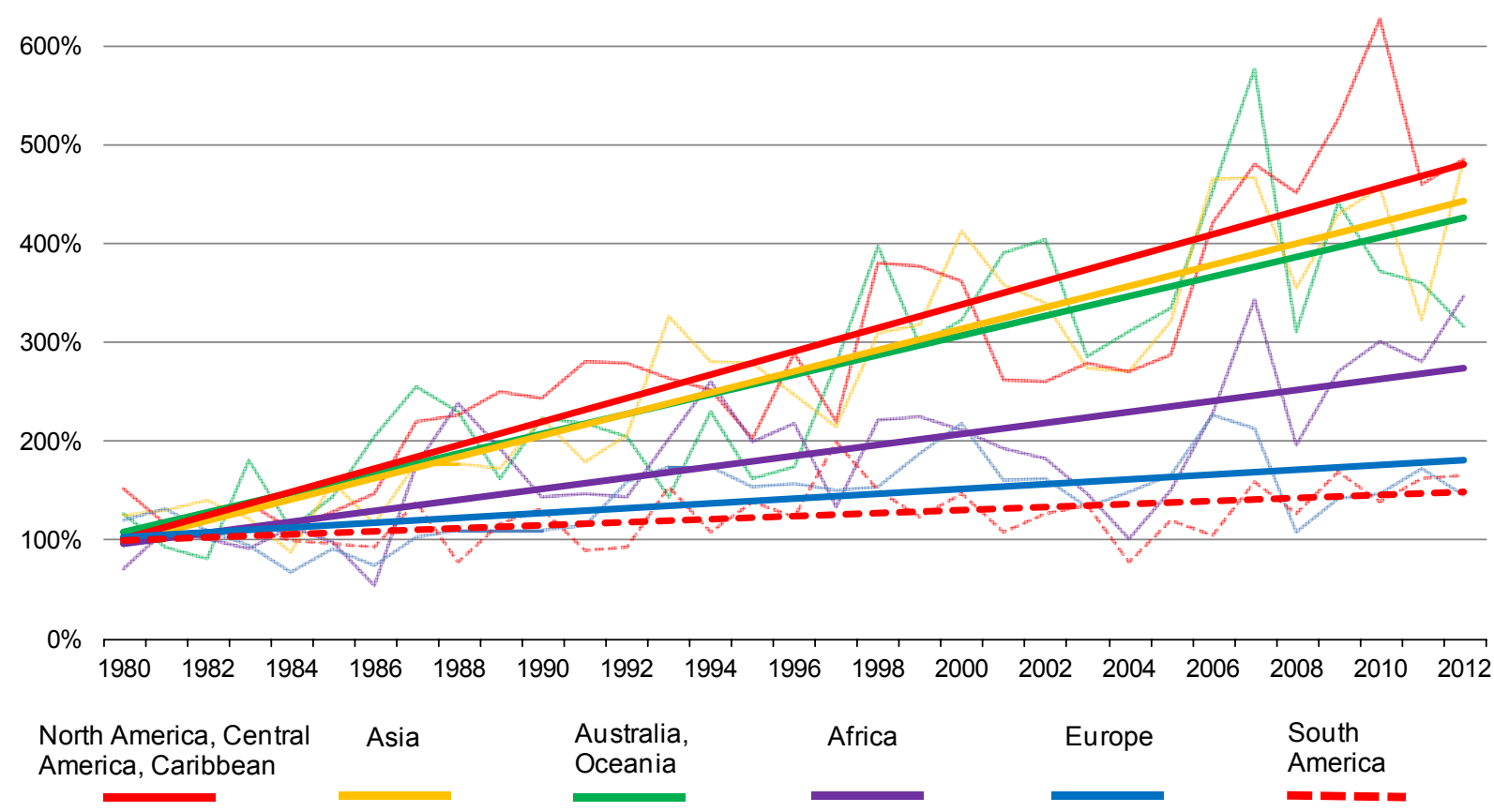

Figure 3. Relative trends in weather-related loss events per continent 1980-2012. For the sake of comparability between the linear trends, the annual figures are expressed as a percentage of the value for 1980 as inferred from the linear trend fitted to the absolute figures. As a consequence, the linear trends start from the same $100 \%$ level in the year 1980. Source: Munich Re, NatCatSERVICE

Compared with other continents, the trend in the number of weather-related loss events is steepest for North America, confirming the need to address the changing risk situation there. To create comparable data, relative figures must be used, i.e. the annual figures are expressed as a percentage of the value for 1980 determined from the trend curve of the respective absolute figures (Figure 3). Of the 3200 loss events from 1980 to 2012, 66\% are attributable to various kinds of storm, $15 \%$ to floods, and 19\% to wildfires, heatwaves and droughts (Figure 4).

The overall loss burden from weather catastrophes for the period concerned was US\$ $1150 \mathrm{bn}$ (in 2012 values), the most expensive category, storms, accounting for $76 \%$. Floods contributed $8 \%$ and climatological events $16 \%$. The costliest single events (figures given in original values) were Hurricane Katrina in 2005 (US\$ 125bn) and Hurricane Sandy 2012 (US\$ 65bn).

Insured losses in respect of weather-related perils amounted to US\$ 560bn in the period 1980-2012. Due to high penetration for storm insurance, meteorological events accounted for $88 \%$, followed by climatological events $(9 \%)$ and hydrological events (3\%). The costliest event recorded in the USA and worldwide in terms of insured losses (in original values) was Hurricane Katrina in 2005, with insured losses of US\$ $62 \mathrm{bn}$. Katrina's loss share can be segmented into property losses of US\$ $41 \mathrm{bn}$, offshore losses of US\$ $5 \mathrm{bn}$ and water-related losses covered by the National Flood Insurance Program of US\$16bn. Insured losses in the United States from Hurricane Sandy in 2012 were US\$29bn.

Around 20000 lives have been lost due to weather catastrophes in the USA since 1980. Half of these fatalities were caused by climatological events (predominantly heatwaves). The deadliest single storm event was Hurricane Katrina in 2005, when more than 1300 people died, but the series of devastating thunderstorms that hit the USA in 2011, the deadliest in over 75 years, also claimed more than 600 lives. 


\section{0 loss events}

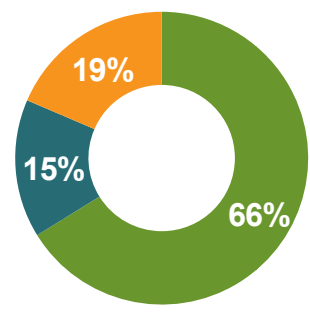

Overall losses US\$1150bn*

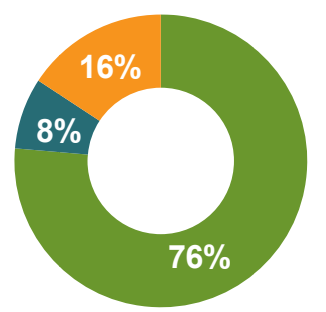

\section{0 fatalities}

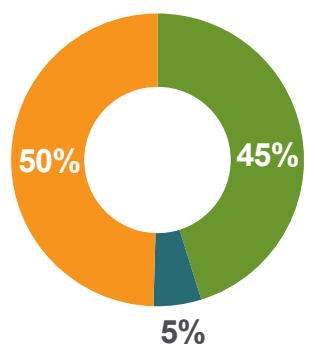

Insured losses US\$ 560bn*

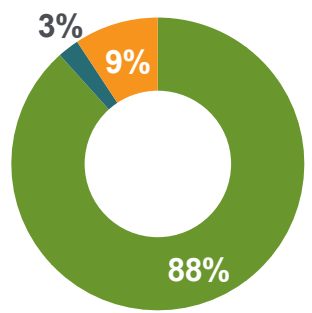

\section{Climatological events}

Hydrological events

Meteorological events

* In 2012 values

Figure 4. Weather catastrophes in the USA 1980-2012: Percentage distribution by peril. Source: Munich Re, NatCatSERVICE

Like the number of weather catastrophes, the losses they caused in the USA is seen to be increasing (Figure 5). Even disregarding 2005 (a record year with Hurricanes Katrina, Rita and Wilma), overall and insured losses (adjusted for inflation) reveal an upward trend over the past three decades. It is also noteworthy that annual thunderstorm losses can reach the same levels as hurricane losses, even though the latter have much higher loss potential per event, as Hurricane Sandy confirmed. The fifth costliest year of this period for the insurance industry, 2011, was dominated by convective storm losses (Figure 6).

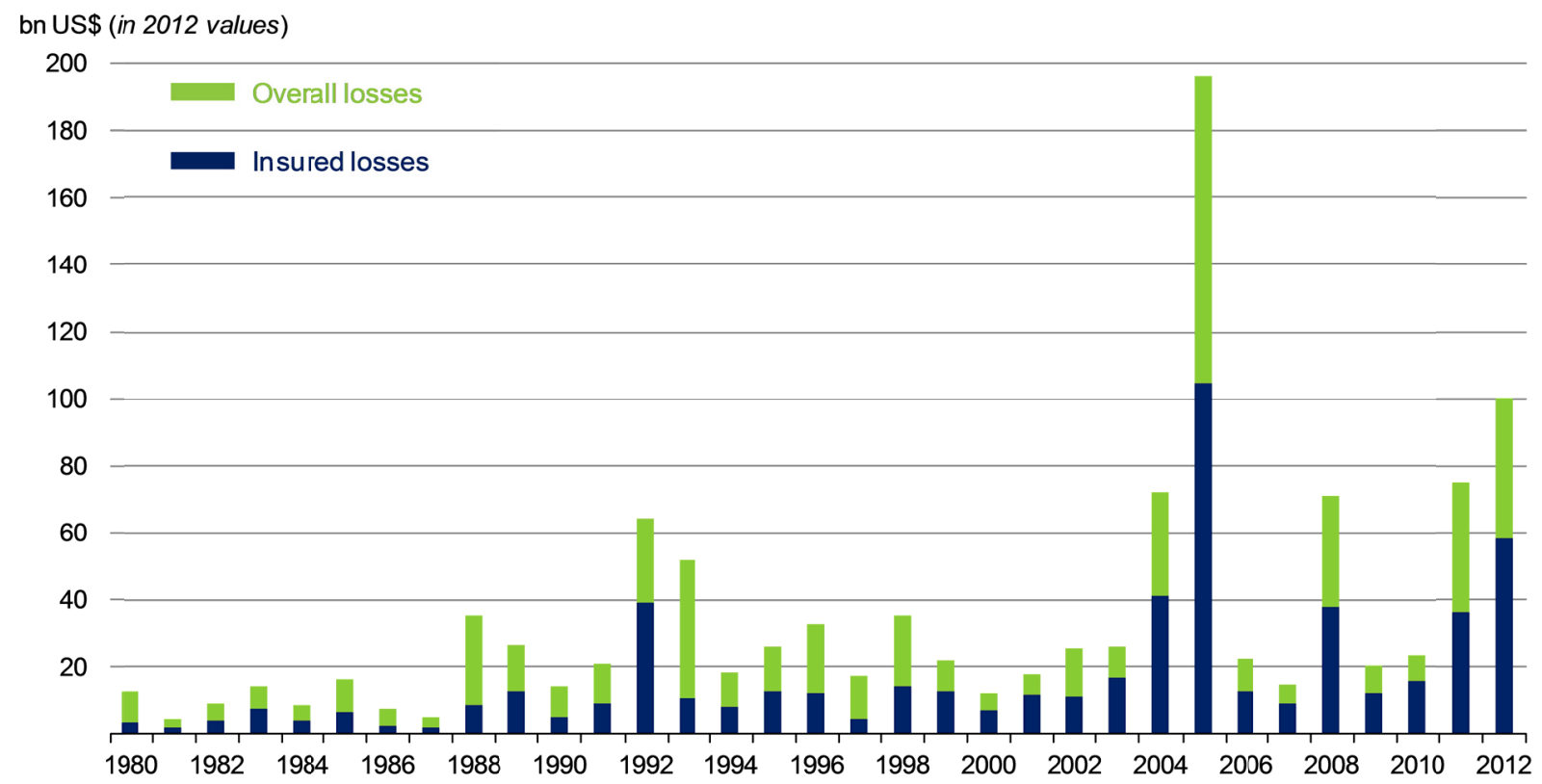

Figure 5. Weather catastrophes in the USA 1980-2012: Overall and insured losses (US\$ bn, 2012 values). Source: Munich Re, NatCatSERVICE 


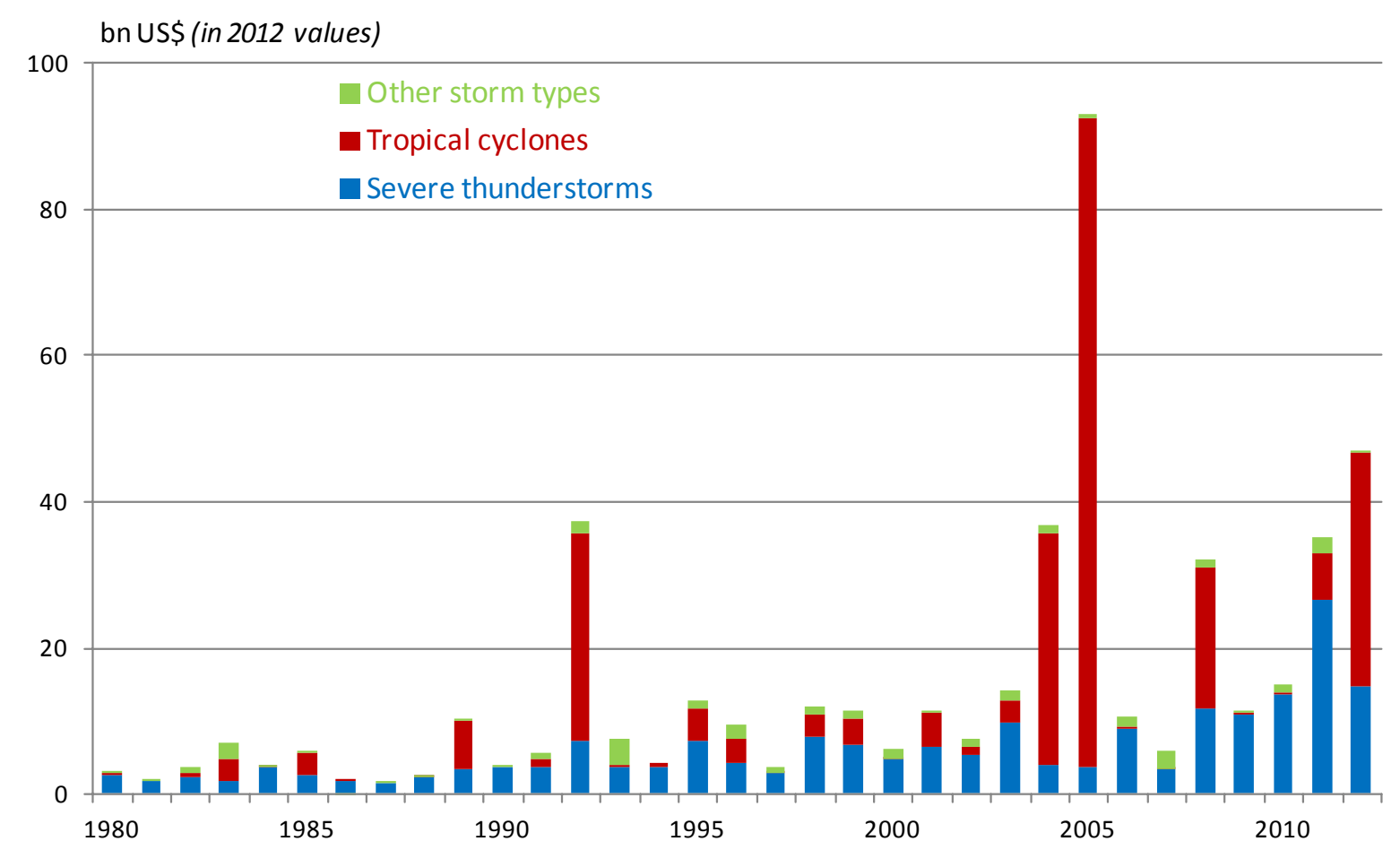

Figure 6. Insured annual property losses (NFIP included, offshore platform losses excluded) due to various types of storm in the USA 1980-2012, in 2012 values. Source: Munich Re, based on own data (NatCatSERVICE) and data from the ISO's Property Claims Service

\section{Tropical Cyclones}

Tropical cyclones are the most feared and devastating weather events along almost the entire North American east and Gulf coasts - especially if they develop into hurricanes. Eight individual storms have resulted in damage in the USA caused by wind, storm surge, rain and waves in the 10+ billion dollar range. The main loss driver is the concentration of people and assets at the coast combined with high and possibly growing vulnerabilities. In recent years, storm surge risk has moved more and more into focus. Effects of climate change have not yet clearly been identified from observations, but a rising sea level and higher ocean temperatures will most likely lead to increasing impacts from such events (IPCC, 2013).

Tropical cyclones develop from storm cells over tropical oceans. They are fueled by water vapor rising aloft as surface water evaporates. At surface temperatures of $27^{\circ} \mathrm{C}$ and above, tropical cyclones can form. They generally travel west-northwestward as tropical storms or even hurricanes. On average, 15 tropical storms, of which eight reached hurricane force, have developed per year since 1995.

\subsection{Hazards and Damage}

\subsubsection{Wind}

Wind is the main primary hazard associated with tropical cyclones. If it reaches hurricane force (at least $118 \mathrm{~km} / \mathrm{h}$ ), a tropical cyclone is classified as a hurricane. If the wind does not reach hurricane force, a tropical cyclone is referred to as a tropical storm, with wind speeds of $63-117 \mathrm{~km} / \mathrm{h}$. Tropical cyclones accompanied by hurricane-force winds are classified on the five-stage Saffir-Simpson Hurricane Scale (SSHS), based on maximum wind speed.

The highest wind speeds are observed at the eyewall, i.e. the region closest to the eye of the storm. Within the eye, there is little wind. The rotational speed of the air is augmented or reduced by superimposition of the forward speed (rate of advance) of the system. Thus, in the northern hemisphere, the storms are usually more destructive on the right side than on the left. Tropical cyclones typically rapidly weaken when traveling over land but are capable of wreaking considerable destruction even several hundred kilometers inland. 


\subsubsection{Storm Surge}

Storm surge, probably the most important secondary hazard connected with tropical cyclones, is frequently associated with very high losses. A storm surge is a rise in water level that occurs if the wind blows in the same direction long enough to force the water towards the land. The height of a storm surge depends not only on the wind speed of a tropical cyclone at landfall but on its preceding development. The height is influenced by the extent of the windfield, the forward speed of the storm as well as bathymetry and coastal geometry. Additionally the low pressure of the tropical cyclone affects the surge water level. Comparatively weak North Atlantic hurricanes - in terms of wind speed at landfall - can cause exceptionally high surges. Hurricanes Katrina and Ike, with SSHS Categories 3 and 2 at landfall respectively, triggered storm surges greater than any previously associated with these categories. Katrina's $8.5 \mathrm{~m}$ surge was one of the highest values ever measured even on a global scale and was mainly caused by the storm still being a Category 5 on the open ocean. Hurricane Sandy, which had already weakened to a tropical storm at landfall, recently confirmed that a storm's track and forward speed can be more important than its intensity, as it hit the coast perpendicularly driving masses of water ashore. One of the most serious effects of global warming is accelerating sea level rise, which will increase the risk of storm surge and coastal erosion along all North America's coasts (IPCC, 2014).

\subsubsection{High Waves}

Strong winds can generate extremely high surface waves. When Hurricane Ivan swept across the Gulf of Mexico in September 2004, it produced waves exceeding $30 \mathrm{~m}$ in height from crest to trough, and possibly measuring as much as $40 \mathrm{~m}$ in height near the eyewall. Apart from ships, offshore structures are primarily at risk, but the force of the waves may cause structures close to or on the shore (e.g. bridges, quays and harbor facilities) to collapse. High waves can exert forces that even appropriately constructed buildings are unable to withstand.

Wave action was also the factor that made Ivan the most expensive hurricane for the oil and gas industry in the Gulf of Mexico. Some 574 platforms - three-quarters of the manned platforms - and 69 of 117 drilling rigs (three in five) had to be evacuated. Seven rigs sank and five drifted away from their original location. Katrina's waves destroyed the Highway 90 bridge across Biloxi Bay, Mississippi.

\subsubsection{Rainfall}

Over the warm ocean, tropical cyclones absorb immense water masses which are released in the form of rain, primarily when the cyclone makes landfall or crosses mountainous or hilly terrain. The amount of local precipitation is further increased if the storm advances very slowly so that most of the rain falls in the same area. Extreme precipitation with total rainfall of $1000 \mathrm{~mm}$ and up to $760 \mathrm{~mm}$ in a single day was observed during Tropical Storm Allison, in June 2001.

Rainfall may affect a much more widespread area than destructive winds. Its spatial distribution tends to be unequal. Hence floods that build up along large rivers are rarely being generated. However, local intensities may exceed $100 \mathrm{~mm}$ per hour, so that natural and artificial drainage capacities are overwhelmed, leading to disastrous local and regional floods, sometimes accompanied by landslides. Rain increasingly determines the amount of loss the further inland the storm moves. Rain is also the prime factor when a former tropical system adjusts to the different meteorological conditions prevailing in the middle latitudes and becomes an extratropical transition. This primarily affects the northeast coast of the USA.

\subsection{Exposed Regions}

The entire North American coastlines of the Atlantic Ocean and the Gulf of Mexico from Newfoundland to the Mexican border are exposed to tropical cyclones. Along large stretches of this coastline, Category 3 (SSHS) wind speeds or even higher can be expected once in 100 years on average. The distribution of hurricanes varies greatly from one stretch of coastline to another. More than a third of all U.S. landfalling hurricanes hit Florida (Figure 7). Combined with an enormous increase in values over the past 80 years, this makes Florida the principal driver of hurricane losses.

Along the Gulf of Mexico coastline, historically high hurricane density represents a constant threat to the population. Along the Atlantic coast, the further north, the more sparse the distribution of hurricanes. The rareness of events north of Cape Hatteras probably led many people to underestimate the risk. Sandy has probably changed this attitude - at least for the time being. 


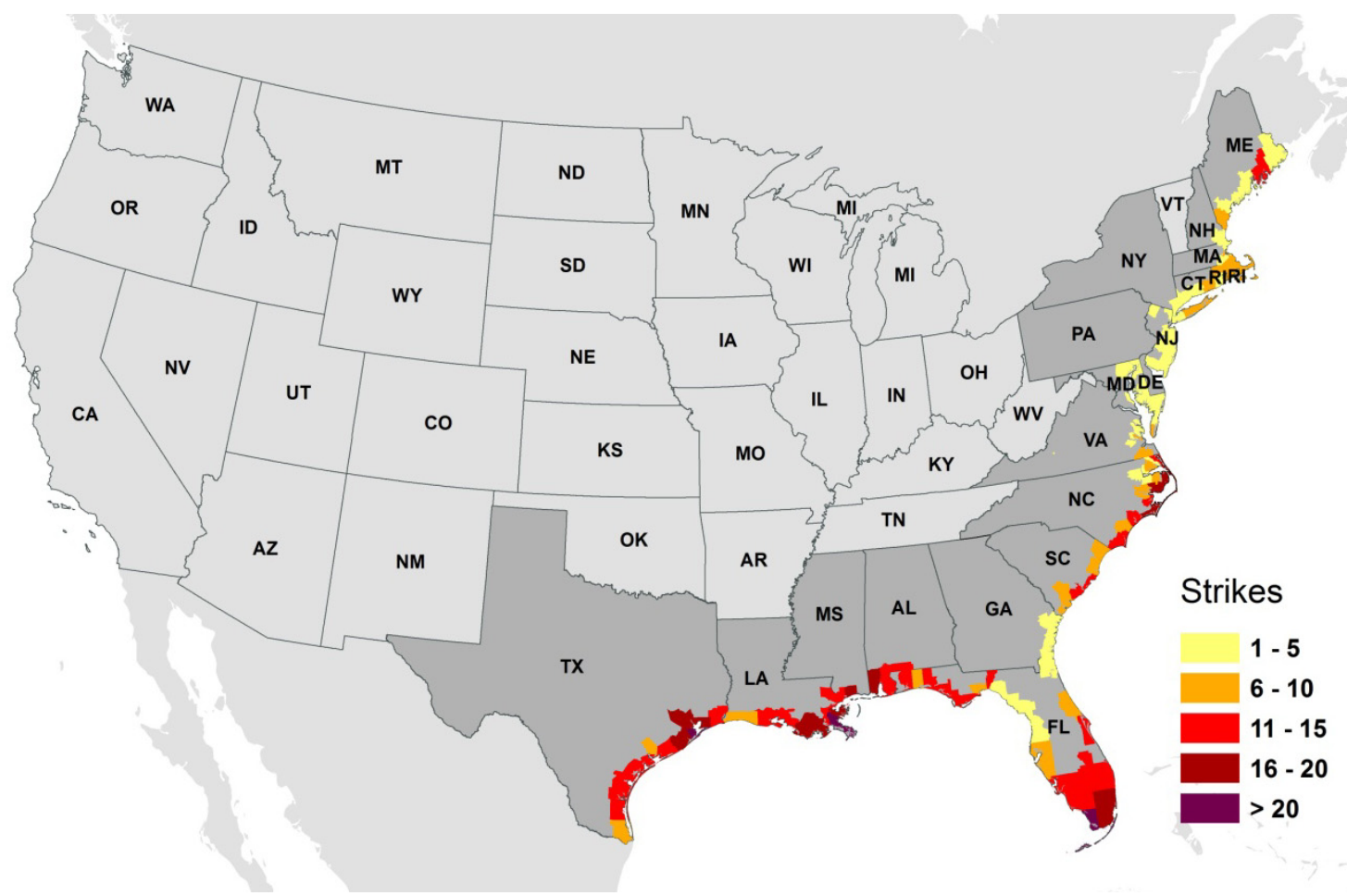

Figure 7. Map of historical landfalling hurricanes per county on the U.S. coastline from 1900-2008. Source: Munich Re, based on data from NOAA, National Hurricane Center

\subsection{Mitigation Measures}

Protecting infrastructure is a crucial task of the government authorities. The continued operation of traffic, communications, water, wastewater and, above all, power systems, or at least their resilience, must be assured, so that normal service can be quickly resumed following shutdown. Hurricane Sandy dramatically showed how much life in a city (and elsewhere) is dependent on such systems. While, in the past, vulnerability to wind damage seemed more problematic, water has proved a more and more crucial factor - and especially salt water due to surges. It will be very difficult to decide whether to construct extremely costly tidal defenses promising high safety levels (e.g. surge barriers) and reduce overall vulnerability by means of on-site strengthening and protection measures, or to accept a certain level of risk.

On the private homeowner level, preventive measures such as boarding up windows and installing roof protections can also help reduce losses, particularly in the case of weaker storms, where most damage is caused by uprooted trees and falling branches. Regular pruning of trees near buildings helps prevent damage, and parking cars in garages avoids dents and broken windows. Robust roof structures and materials, and regular building rehabilitation work also reduce the risk of significant structural damage. Finally, using or storing expensive items in the basement and on the lower levels of buildings is to be avoided, a fact a number of New York art galleries learned the hard way during Hurricane Sandy.

Forecasts have become much more accurate in recent decades. Every six hours during the life of a tropical storm in the North Atlantic, the National Hurricane Center (NHC) issues official forecasts regarding the position of the eye, maximum wind speed and the radii of given wind speeds, and the radius of $64-\mathrm{knot}(118 \mathrm{~km} / \mathrm{h})$ wind speeds for all storms. Evacuation, a very difficult issue, is sometimes crucial. The problem with early warning is the uncertainty involved. Hurricane Irene was expected to have a disastrous impact on the northeast but weakened in terms of wind speeds so that losses were mainly caused by the intense rainfall experienced in some states. The authorities were subsequently accused of alarmism. Often the result of these (ostensibly) false warnings is that people do not react if the situation arises a second time - with potentially drastic consequences. However, the threat posed by Hurricane Sandy met with the appropriate response. Despite improvements in forecasting and protection measures, most hurricane losses will remain unavoidable. 


\section{Extratropical Cyclones}

Extratropical cyclones rely on temperature gradients between different air masses to develop. Since temperature gradients in the mid-latitudes are much larger during winter than summer, extratropical cyclones are more intense during the winter months. Here we refer to these storms therefore as winter storms.

Several dozen winter storms impact North America every year, though only a few cause severe damage. However, severe winter storms have a much greater geographical footprint than other meteorological perils. Frontal systems associated with a winter storm can stretch for thousands of kilometers, causing a variety of weather along their length.

\subsection{Hazards and Damage}

Winter storms produce several hazards that are unique to that peril, including snow, sleet (precipitation composed of frozen raindrops), freezing rain and freeze. However, they can also produce hazards not exclusive to winter storms such as high winds (including tornadoes), large hail and excessive rainfall that can trigger flooding and landslides. Storm surges may also be generated.

The dominant winter storm hazards along the west coast are strong wind and severe rain events affecting coastal regions, with heavy snowfall at higher elevations. Torrential rains in Southern California often trigger devastating mudslides and flooding as well. In the Intermountain West region and northern parts of the Great Plains, heavy snowfall and arctic air outbreaks are the primary hazards, whereas in the southern Plains and the southeast USA, heavy rainfall and severe thunderstorms are the most common hazards associated with winter storms. Freezes can extend into this region as well, and even southern Florida is not immune to sub-freezing temperatures on occasions. Finally, the northeastern USA is exposed to all forms of frozen precipitation, particularly heavy snowfalls and the high winds associated with powerful coastal winter storms known as nor'easters. Arctic outbreaks of cold air and severe freezing rain events are also possible, as are heavy rain events when temperatures are not cold enough to support snow.

Frozen precipitation creates hazardous driving conditions and often leads to traffic accidents. Buildings can be damaged by ice damming, when snow and ice prevent melt water from draining from a rooftop. The water may back up under the shingles, damaging the roof structure, insulation and drywall below. Very large snow loads can lead to partial or total roof collapses, particularly on flat roofs with little drainage and few underlying supports. However, thanks to good regional building codes that take into account snow loads, instances of roof collapse are relatively rare, even in heavy snowfall events. Large accumulations of freezing rain add a tremendous amount of additional weight to objects they collect on, and often cause the branches of trees and power lines to snap. In severe events, the glazing produced can be several centimeters thick and bring down larger structures like high voltage transmission towers. Apart from the risk they pose to health and agricultural interests, prolonged cold air outbreaks can cause property damage by rupturing of frozen water pipes. Heavy rainfall associated with winter storms can also cause severe flooding, particularly if the rain contributes to snowmelt or the ground is frozen.

\subsection{Loss Potentials}

Despite the number of different hazards and large geographic scope of winter storms, loss potentials are typically not as severe as those from tropical cyclones and thunderstorm perils. Since 1980, the largest insured winter storm loss has been US\$ 2bn, resulting from the 1993 "Storm of the Century" nor'easter that generated hurricane-force winds along the U.S. east coast and left over $30 \mathrm{~cm}$ of snow from Georgia to Maine. Winter storm losses over the ten-year period 2003-2012 averaged US\$ 1.2bn per year. The extreme winter of 2014 exceeded this figure considerably. The average figures for tropical cyclones (US\$ 18.2bn) and thunderstorms (US\$ 10.6bn) are much higher (cf. Figure 6).

The most likely scenario regarding a major, multi-billion-dollar insured loss would be similar to the 1998 ice storm (freezing rain) in northern New England and Ontario, Quebec. During the event, several centimeters of freezing rain fell on the area, causing trees, power lines, and high voltage transmission towers to collapse, leaving parts of the region without power for weeks. More than US\$ $1 \mathrm{bn}$ in insured losses were incurred in Canada, particularly around Montreal, and in the USA. A similar event over densely populated regions of the USA, such as the Northeast Corridor or over Midwestern cities like Chicago and Detroit, could cause losses several times greater than the 1998 event, potentially exceeding US\$10bn. 


\section{Local Storms/Thunderstorms}

A towering cloud with strong updrafts and downdrafts is called a severe local storm or thunderstorm. It is driven by convection, in which moist warm surface air rises aloft within a cooler upper level environment. Thunderstorms may be accompanied by various perils including high winds, heavy precipitation and tornadoes. Precipitation may fall as hail, and heavy rainfall can cause flash floods.

Thunderstorms are classified according to their dimensions and the way in which they form. A typical single-cell storm is an isolated summer thunderstorm lasting no more than 30 to 60 minutes on average and not involving any major hazards. Multicell storms have a longer lifespan. Supercells can form if there is a substantial difference between wind speed and direction at ground level and at altitude. Known as quasi steady-state storms, they are the most severe type of thunderstorm, and can even continue throughout the night. They have extremely high loss potential, as they can cause not only strong wind gusts and heavy precipitation but also large hailstones and significant tornadoes. Thunderstorms can form along a cold front or narrow corridor where air flows converge, giving rise to the development of a squall line, which consists of thunderstorm cells arranged along a line that can extend up to several hundred kilometers in length. A "derecho" is an extremely violent type of squall line.

Two parameters can be combined to indicate severe thunderstorm potential, i.e. the propensity for severe thunderstorms to form over a given region: (a) the Convective Available Potential Energy (CAPE), a measure of the energy available to form a thunderstorm, and (b) vertical wind shear, i.e. the difference between wind speed and direction near the surface and at approximately $6 \mathrm{~km}$ altitude (Munich Re, 2012). The organization, intensity, lifespan and track length of severe thunderstorms largely depend on the vertical wind shear. Huge supercell thunderstorms can travel distances of more than $1000 \mathrm{~km}$.

\subsection{Hazards}

\subsubsection{Tornadoes}

A tornado is a narrow, violently rotating column of air that extends from the base of a thunderstorm cell to the ground. The average width of tornado funnels is about $100 \mathrm{~m}$ and the average track length a few kilometers, although widths of more than four kilometers and track lengths of more than $300 \mathrm{~km}$ have also been observed (Edwards, 2014). The maximum possible wind speed on the edge of the funnel is estimated to exceed $500 \mathrm{~km} / \mathrm{h}-$ the highest speed of all windstorm phenomena. Tornadoes are classified into six classes on the Enhanced Fujita Scale (EF0 to EF5) according to their maximum wind speed (Fujita, 2006).

In "Tornado Alley", a wide corridor that extends from Iowa and Nebraska to Texas, the prevailing conditions favor the formation of severe thunderstorms and significant tornadoes (EF2 and stronger) more than anywhere else in the world (Figure 8). Due to the lack of a major mountain barrier to separate them, cold, dry polar air masses from the northwest and moist warm tropical air masses from the Gulf of Mexico converge over the region's relatively level topography, causing strong convective activity, i.e. severe thunderstorms.

Natural climate variability, such as El Niño and La Niña phases, has an impact on severe thunderstorm activity in North America (Bove, M. C., 1999; Cook \& Schaefer, 2008). During strong La Niña phases, the region frequently hit by significant tornadoes (EF2 - EF5) during winter and spring extends markedly eastwards from Tornado Alley, whereas El Niño phases tend to spawn tornadoes more often in southern parts of the USA.

\subsubsection{Straight-Line Winds}

Winds can reach hurricane force in thunderstorms, and are referred to as straight-line winds to distinguish them from tornadoes. Straight-line winds are the horizontally deflected outflow of a thunderstorm's downdraft. A strong downdraft that induces potentially damaging winds at or near ground level is known as a downburst. Severe thunderstorms with downdrafts exceeding $100 \mathrm{~km} / \mathrm{h}$ occur throughout the eastern USA. Storm cells with very high downdraft speeds occur predominantly in a corridor that extends from Nebraska and Iowa to Texas, which is about the same region as for large hail. 


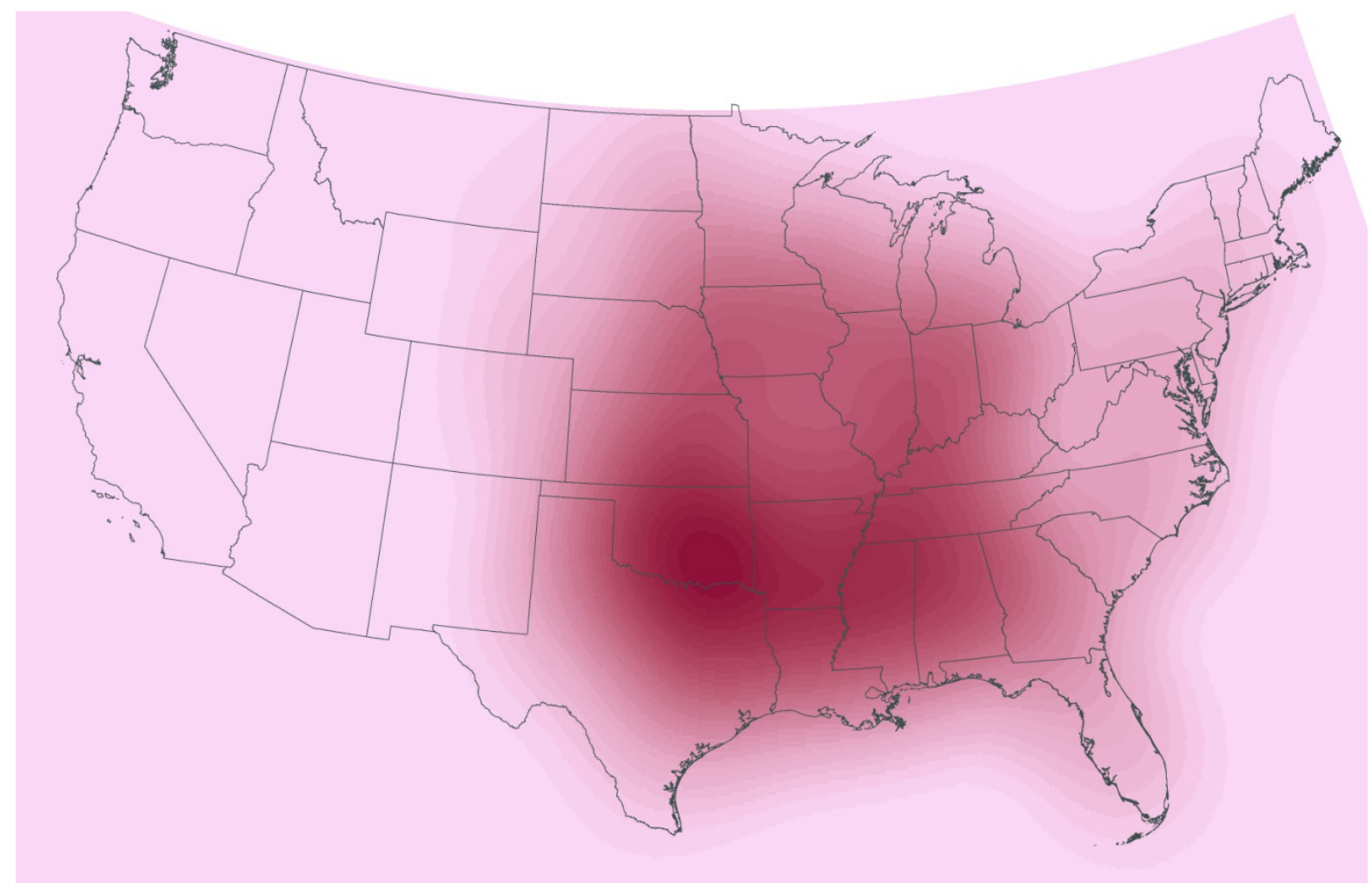

Figure 8. Spatial distribution of tornadoes with intensity EF2-EF5. The darker the shading the higher the frequency. The map is based on observations in the period 1950-2009. Source: Munich Re, based on data by NOAA, National Severe Weather Database of the Storm Prediction Center

\subsubsection{Hail}

Hailstorms require the presence of strong updrafts within the storm cell that carry fine water droplets upwards to altitudes where the temperature is well below freezing. Once they reach a certain weight, gravity causes them to sink to lower altitudes, where they are again borne up to higher levels by stronger updrafts. This process is repeated, and the hailstones increase in size with each successive layer until, too heavy to be borne aloft by the updrafts, they fall to the ground. The terminal velocity of hailstones increases in proportion to the square root of their diameter. Thus, a $1 \mathrm{~cm}$ hailstone impacts at a speed of around $50 \mathrm{~km} / \mathrm{h}$, compared with $170 \mathrm{~km} / \mathrm{h}$ in the case of a $13 \mathrm{~cm}$ specimen - sufficient force to kill a person. Hail swaths can vary in magnitude from a few acres to over $15 \mathrm{~km}$ in width and $150 \mathrm{~km}$ in length.

\subsubsection{Lightning}

Lightning strikes do not have the high loss potential of the above-mentioned hazards, but can trigger severe consequences locally such as a power outage or a wildfire, and destroy electronic equipment.

\subsubsection{Flash Floods}

Most flash floods are caused by thunderstorms. Run-off occurs often at high velocity and with extreme destructive force. The destructiveness is increased by floating matter, transported sediment, ground and channel erosion, and the undermining of building foundations. Flash floods can happen anywhere, without exception. Most are unexpected events. Streams in particular can be transformed in a matter of minutes from gently flowing brooks to raging torrents, eroding embankments and river beds. Protective measures are normally not an option and often human lives are lost. Flash floods are one of the most frequent causes of death from natural disasters in the USA (Ashley \& Ashley, 2008). Fortunately, they are generally of limited duration and, after a few hours, the water will have receded.

\subsection{Damage and Mitigation Measures}

Tornadoes have huge loss potential due to their high wind speeds. The damage is mainly caused by wind pressure and flying debris. However, since a tornado's corridor is relatively narrow, a few hundred meters can determine whether it leaves a trail of devastation through a residential or industrial area or causes minor losses in an 
uninhabited region. Protecting property against significant tornadoes is an expensive undertaking because tornado-resistant construction requires substantial engineering input. The best solution in terms of protecting lives is the availability of a basement to provide shelter during a severe weather warning.

Proper construction techniques are also critical in reducing losses from straight-line wind damage. Buildings should be constructed with continuous load paths in the walls and proper roof-to-wall and wall-to-foundation connections. Exterior doors should open outwards, windows should be impact-resistant and garage doors reinforced (IBHS, 2012).

The damage and loss amounts caused by strong hailstorms are primarily determined by the size of the hailstones. Appreciable material damage results (e.g. to roofing materials and vehicles) if the hailstones are more than about $2.5 \mathrm{~cm}$ in diameter. Hailstorms can damage roofs, façades, cladding and windows. A hailstorm may also result in a large number of individual motor losses that add up to a substantial total amount. Even small hailstones can damage crops. Beside hail size, the loss is also determined by the type of crop and its growth stage. A complete harvest can be wiped out by a long and extensive hail swath. It is possible to prevent hail damage to buildings through the application of suitable building materials, such as hail-resistant roofing and siding. Nets can be used to protect vehicles parked in open-air depots and sensitive crops. Further precautions include measures such as ensuring vehicles are not left outside if a severe storm is forecast.

Lightning strikes can damage the roof or chimney of a building. Due to the enormous heat generated, almost any material will melt if a lightning current passes through it, potentially resulting in a fire or even an explosion. Electrical equipment can also sustain indirect damage from lightning-induced power surges if the building itself is struck or if power and communication lines are hit, and then relay the surge to the equipment. In this way, lightning can cause damage within a radius of one kilometer or more of the strike. Loss potential has increased in recent decades with the growing number of electronic devices (computers, television and even kitchen appliances, etc.) susceptible to voltage fluctuations. Damage to structures and installations can be largely prevented if a lightning protection system is installed.

Severe thunderstorms have enormous loss potential. In 2011, for instance, the USA suffered US\$ 47bn in overall losses due to tornadoes, hail, wind gusts and flash floods that accompanied severe thunderstorms. This was almost half the loss inflicted by Hurricane Katrina in 2005 and five times that caused by Hurricane Irene in 2011. Hence thunderstorms following tropical cyclones are the most important severe weather hazard for the U.S. insurance industry.

\section{The Concept of Risk}

The term risk is understood and used in many different ways. While this plurality of usage may be of no consequence, risk should be defined and used in an unambiguous and consistent way. Natural catastrophe risk is the probability-based expected outcome of a process in which an impact on a system (caused by a natural phenomenon) results in negative consequences - i.e. the impact affects that system's status. Risk consideration therefore requires an impact, a system and the system's reaction to the impact (Kron, 2005).

In the context of natural catastrophes, the scientific community agrees that risk is the product of a hazard and its adverse consequences to people and their belongings. Where there are no people or values that can be affected by a natural phenomenon, there is no risk. Similarly, an event is only termed a catastrophe if people are harmed and/or their possessions damaged. This is demonstrated by the following three scenarios:

- A very strong storm in an uninhabited region cannot result in a catastrophe (no risk).

- Neither can a strong storm in a region that is well prepared for the catastrophe (low risk).

- In a third scenario, however, even a moderate storm may cause a devastating catastrophe in a poorly prepared region (high risk).

The storm hazard is clearly highest in the first case, while the storm risk is highest in the third case. Hence, three components determine the risk:

$\mathrm{H}$ The degree of hazard, i.e. the varying intensities of threatening natural events, including their probabilities of occurrence;

E The total exposed values or values at risk - real/personal property - and people present at the location affected/threatened;

$\mathrm{V}$ The degree of vulnerability, i.e. the lack of resistance to damaging forces. 
In its simplest form, the total risk $\mathrm{R}$ is calculated by multiplying the three components:

$$
\mathrm{R}=[\mathrm{H}] \cdot[\mathrm{E}] \cdot[\mathrm{V}]
$$

In the insurance industry, a further component is crucial:

I Insurance penetration, or the proportion of insured values at risk.

Thus, the insured risk $\mathrm{R}_{\mathrm{i}}=[\mathrm{H}] \cdot[\mathrm{E}] \cdot[\mathrm{V}] \cdot[\mathrm{I}]$. All components are, or may be, probability-distributed variables, which is indicated by the brackets. This is obvious in the case of the hazard, which occurs in varying intensities associated with different probabilities, but the values at risk, and especially vulnerability, may also vary over time. Examples illustrating these two cases are fluctuations in the contents of a storage facility and variations in the resistance of a crop to frost, depending on growth stage.

Events become catastrophes if people are killed, injured and/or displaced and/or their possessions damaged or destroyed. Similarly, whether a location is risk-prone depends on a) the likelihood that a natural event may occur and b) the presence of vulnerable items. Hence, it is not the natural hazard as such that accounts for the consequences of an extreme event.

From an insurance perspective, it is particularly important to ascertain the relative contributions of the three components that determine the risk. As a zero-order approach, any increase in insured exposure that regularly produces a higher level of loss, will be balanced by higher premium income. However, changes in loss driven by factors other than exposure are not automatically balanced in that way. If not detected and adjusted in time, they result in systematic underestimation of the risk. Such developing imbalances may even contribute to solvency problems on the part of a natural catastrophe insurer and thus pose a threat to both the insureds and the insurers.

\section{Changing Risk}

\subsection{Socio-Economic Developments}

\subsubsection{Changing Exposure (Values at Risk)}

The dramatic increase in population in certain regions is the main reason why natural catastrophe losses have skyrocketed in recent decades. Enormous amounts of values are concentrated in large metropolitan areas and can potentially be damaged if a single natural hazard event strikes. Turning wasteland into residential and business areas transforms zero-risk locations (with no values) into risky locations. The development of new housing and commercial areas, industrial parks, recreational facilities, etc. in high-hazard areas such as flood plains, hill slopes, beaches, and wildland-urban interfaces exposes more and more values to natural perils. Retirement villages ("sun cities") are good examples of this. Coasts, hills, and streams are attractive to live by, as is owning a property surrounded by woods. The flood, landslide, storm surge, and wildfire hazards are often overlooked.

Nowhere is more attractive to people than the coast. In the USA, 87 million people ( $28 \%$ of the population) now live in coastline counties, compared to just 47 million in 1960. The average population density at the coast has increased from 100 people per square kilometer in 1960 to 185 in 2008 (Wilson \& Fischetti, 2010). On average, the population density of the coastline counties is twice that of the non-coastline counties. Furthermore, people and enterprises now have more, and often higher-value, possessions than ever before. They are frequently concentrated on a specific area. It can be advantageous for companies that manufacture the different components of complex products (such as automobiles) to be located within the same industrial park that offers corresponding infrastructure features. Hazard exposure may well be particularly high in the case of vacation resorts located as close as possible to the beach, and even more so at marinas with hundreds of leisure boats.

\subsubsection{Changing Vulnerability}

Vulnerability may refer to human health (human vulnerability), structural integrity (physical vulnerability) or personal wealth (financial vulnerability). The effect of vulnerability on damage is determined by factors such as construction style, material, and age, together with early-warning, precautionary and preventive measures.

Many buildings and modern items of equipment are highly susceptible to damage. A large number of goods commonly found in households, and more particularly in business and industrial facilities, contain electronic components which are especially prone to damage when exposed to humidity or dust. An important aspect is human perception of security. Building codes and building resistance have improved. Early warning has reached a high level of reliability. Civil defense structures have been established. However, as a result, people may be lulled into a false sense of security, so that they begin to rely entirely on measures like those described above, ignoring the fact that they live in areas threatened by natural hazards. 
The most critical aspect is infrastructure. Traffic, water supply, wastewater discharge, communication, and in particular power networks are absolutely crucial for modern societies. In the USA, many of these systems are aging and need to be modernized and protected. While better protection can prevent losses, a high level of resilience is very important, too. The impact of an extreme event on a community depends mainly on whether its systems are able to recover quickly and downtimes kept to a minimum.

\subsection{Climate Variability and Climate Change}

Hazard is the threat posed by natural processes. The strength of maximum wind speed, the height of a storm surge or the amount of rainfall are more or less beyond our control. We can influence the hazard only in a few cases such as through land management aimed at preventing wildfires, by keeping the natural environment free from combustible material. In the long run, however, there is a way in which humans can influence hazards and that is by mitigating anthropogenic climate change.

While the term weather describes a combination of short-term meteorological conditions such as temperature, precipitation, air pressure, etc. occurring at a particular time and place, the term climate describes the average and the variability of these conditions, including the extreme peaks.

\subsubsection{Natural Climate Variability}

The climate is variable over time. Hence, average conditions or the frequency of extremes as inferred from periods ranging from weeks to centuries (or even longer timescales) can significantly deviate from those conditions as inferred from other periods.

Natural variability over timescales from years to decades is often caused by interactions between the atmosphere and the ocean. Within this coupling, the ocean acts as a transformer, integrating the short-term weather impulses and transforming them into slow oceanic swings and currents. Ocean currents act like huge conveyor belts, transporting warm or cold water to certain regions over extended periods of time, thus modifying regional climates. The two most important aspects in this respect are multi-year or multidecadal oscillations, such as the Atlantic Multidecadal Oscillation (AMO) and the El Niño/Southern Oscillation (ENSO).

\subsubsection{Anthropogenic Climate Change}

A further factor involved in addition to natural climate variability is human intervention. Our climate is currently in a state of change attributable to the influence exerted on the chemical composition of the earth's atmosphere by an industrial civilization (IPCC, 2014). Humans' use of oil, coal, and gas has increased carbon dioxide levels in the atmosphere by some $40 \%$ compared with the pre-industrial era, but atmospheric particle loads have also changed substantially. In addition, large-scale changes in land use (e.g. deforestation, urbanization, changes in reflectivity) also affect regional and local climate. All these changes brought about in the industrial era account for the term anthropogenic climate change.

\subsubsection{Observed Increase in Weather Catastrophes}

In recent decades, the number of natural loss events recorded in the NatCatSERVICE database has increased considerably worldwide. In the USA in particular, weather-related events are responsible for this increase (Figure 9), whereas the number of geophysical events does not display any upward trend. The relative trends in meteorological events (storms) and hydrological events (floods) have approximately quintupled since 1980. 


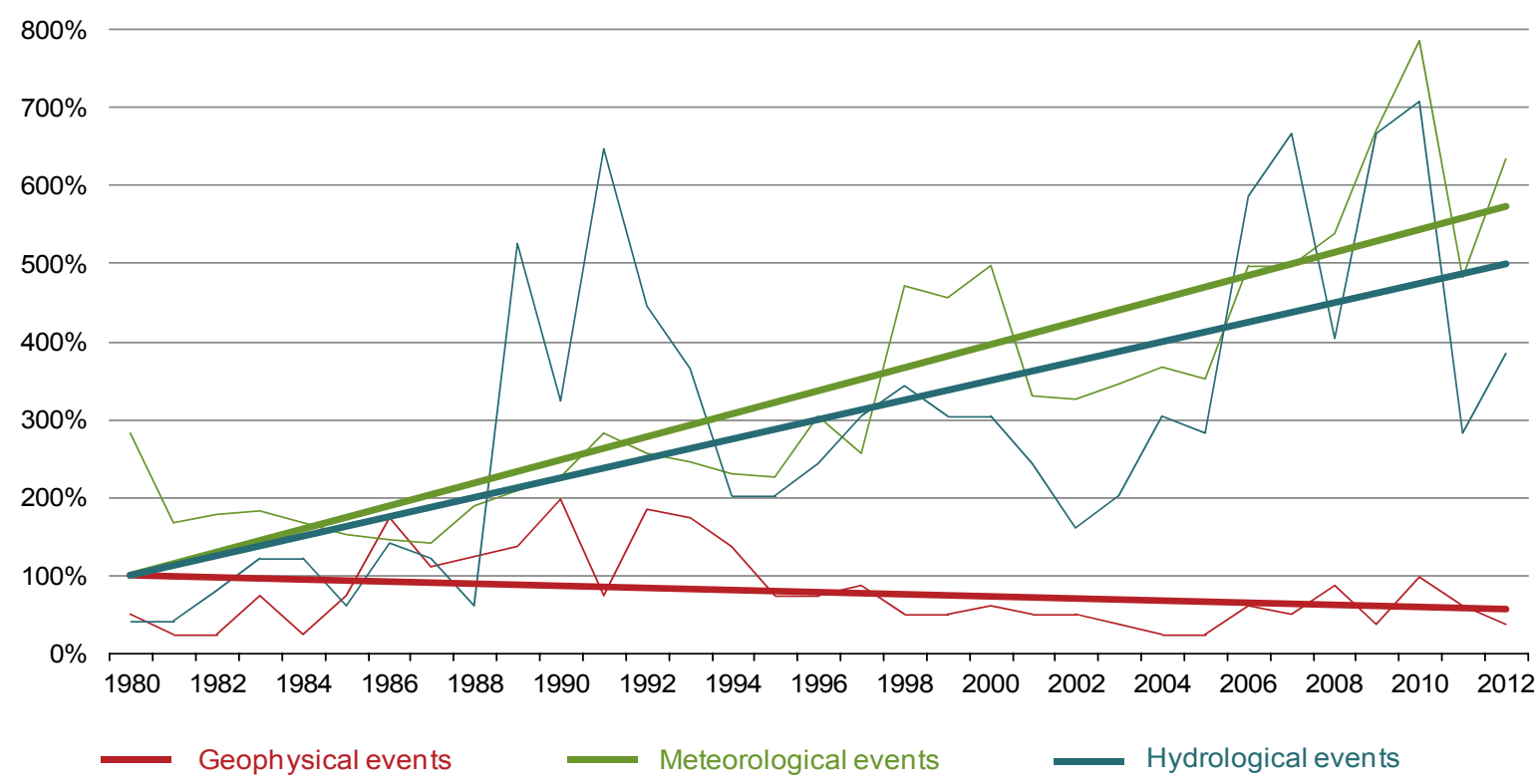

Figure 9. Trends in relative number of loss events from different causes 1980-2012 in the USA. For the sake of comparability between the linear trends, the annual figures are expressed as a percentage of the value for 1980 as inferred from the linear trend fitted to the absolute figures. As a consequence, the linear trends start from the same $100 \%$ level in the year 1980. Climatological events were not included in this diagram due to fragmentary reporting in the 1980s. Source: Munich Re, NatCatSERVICE

The increase in overall and insured U.S. severe thunderstorm losses in recent decades was largely due to socio-economic factors. Besides local population growth, there have been population movements, e.g. from northeastern parts to southern parts of the country. Together, these factors led to sprawling cities and rapid suburban and exurban growth in many regions, thereby creating more areas of exposure accumulation over time that severe thunderstorms hazards can hit. The value of real and personal property has also risen dramatically over this time period, further increasing loss potentials.

Exposure-driven changes in weather losses over time can be removed from a time series by normalization. With normalization, past losses that occurred at different points in time affecting different conditions of wealth are adjusted for changes in destructible wealth, inflation, and - where insured losses are concerned - insurance penetration in the region affected between the year of the event and the present.

Furthermore, small-scale events, e.g. losses from severe thunderstorms, could have been missed in the past because they occurred in unpopulated areas and/or were not reported. If unpopulated areas have been developed in the meanwhile, for instance due to migration from other parts of the country, they will have produced "additional" reported loss events in recent times as compared to the more distant past. Consequently, such events cannot be adjusted by normalization, although today they would produce substantial losses.

Munich Re and the German Aerospace Center (Sander, Eichner, Faust, \& Steuer, 2013) have analyzed severe thunderstorm losses in the USA. Severe thunderstorm events causing normalized overall losses exceeding US\$ $250 \mathrm{~m}$ on average affected more than four states throughout the period $1970-2009$ and hence are unlikely to have been missed at any time. Therefore, to avoid reporting bias, only events exceeding the threshold of US $\$ 250 \mathrm{~m}$ in terms of normalized losses were included in the time series to be investigated. This ensures that such events, which account for some $80 \%$ of normalized losses aggregated over the period $1970-2009$, are registered and reported irrespective of when, during the analysis period, they occurred. The study found a clear upward trend in the time series relating to number of normalized annual overall thunderstorm loss events (Figure 10).

Once the imprint of changes in reporting and in the exposure of destructible assets has been eliminated from the loss data time series, conclusions can be drawn about effects from the other possible drivers such as hazard or vulnerability. 


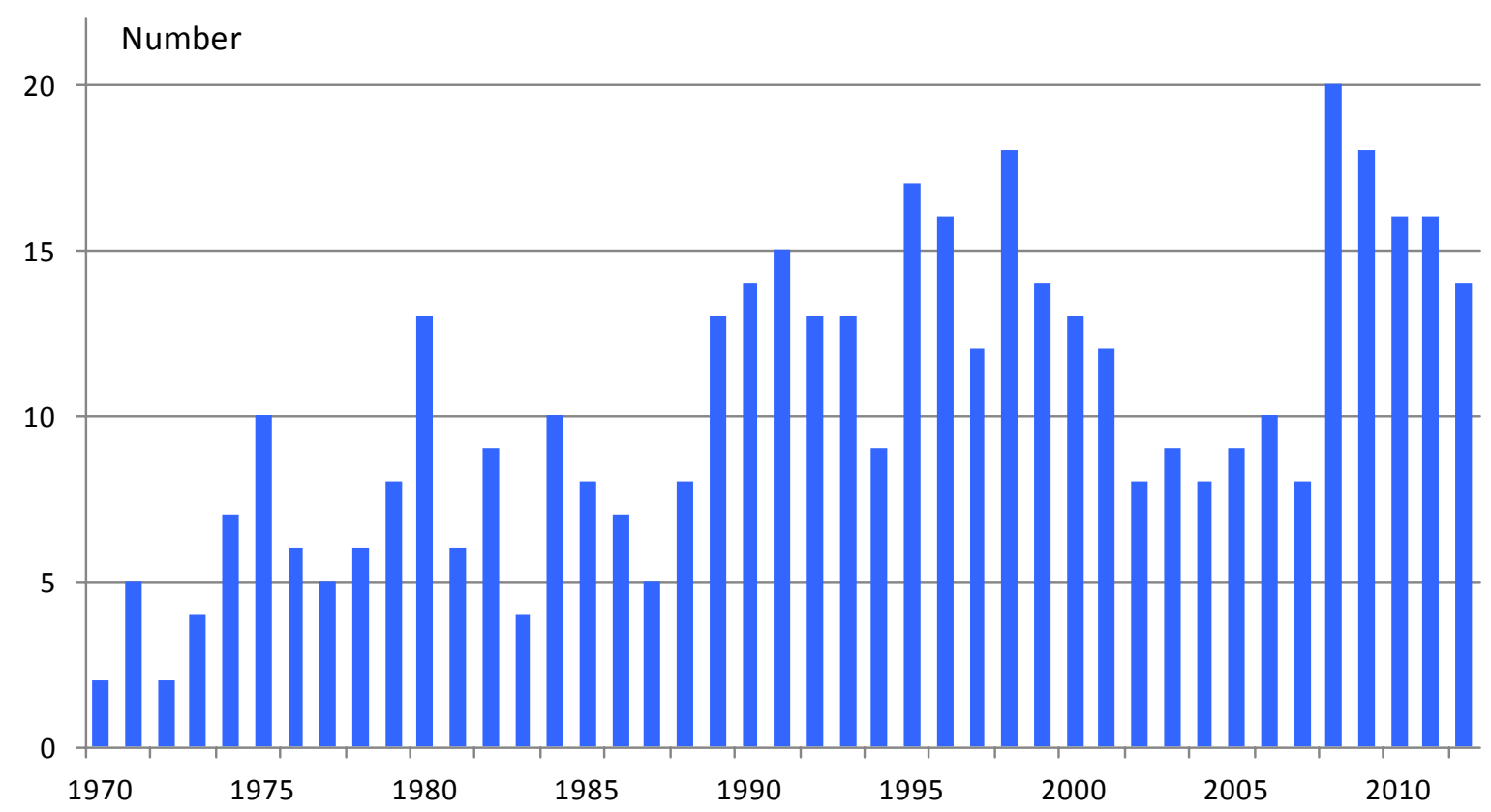

Figure 10. Number of thunderstorm loss events per year in the period 1970-2012 in the USA with normalized overall loss exceeding US\$250m per event. U.S. gross domestic product was used as a proxy for the change in wealth over time. Source: Munich Re, NatCatSERVICE

\subsubsection{Climatic Impacts on Thunderstorms}

Particularly in the first half of the year, El Niño and La Niña phases can have a significant impact on thunderstorm outbreak activity throughout the region east of the Rocky Mountains. During La Niña episodes, the region with the highest frequency of significant tornadoes (EF2 - EF5) is displaced eastwards of "Tornado Alley". The 1974 Super Outbreak occurred in this region during a La Niña phase, as did the two major outbreaks in 2011. In years that have El Niño conditions prevailing from the beginning, the main occurrence region is, on average, displaced to the south. It should be kept in mind, however, that the spatial tendencies described here become visible only when averaged over many El Niño and La Niña episodes. In individual seasons, particularly during weak ENSO episodes, such spatial patterns might not be evident.

Today's climate models cannot spatially resolve individual thunderstorm cells. Thus, climate-driven changes in frequencies and intensities of those phenomena cannot directly be analyzed by climate modeling. However, there is an indirect approach to address the issue of long-term change by analyzing the development of large-scale meteorological conditions that favor severe thunderstorm formation. Meteorological conditions favoring severe thunderstorm formation can be characterized by means of the parameters Convective Available Potential Energy (CAPE) and vertical wind shear (see section 4).

The above-mentioned study (Sander et al., 2013) found that the number of days with conditions favoring the formation of thunderstorms with significant surface winds, hail and/or tornadoes, increased substantially during the period 1970-2010. Calculating the annually aggregated severe thunderstorm potentials based on the simulated data and comparing them to aggregated annual severe thunderstorm losses caused by events with normalized overall losses exceeding US\$250m yielded a close correlation (Figure 11). These results indicate that climatic changes have driven up multi-year averages of thunderstorm-related normalized losses since 1970 and that anthropogenic climate change, most likely responsible for increasing levels of humidity over time, is fully consistent with this change. 


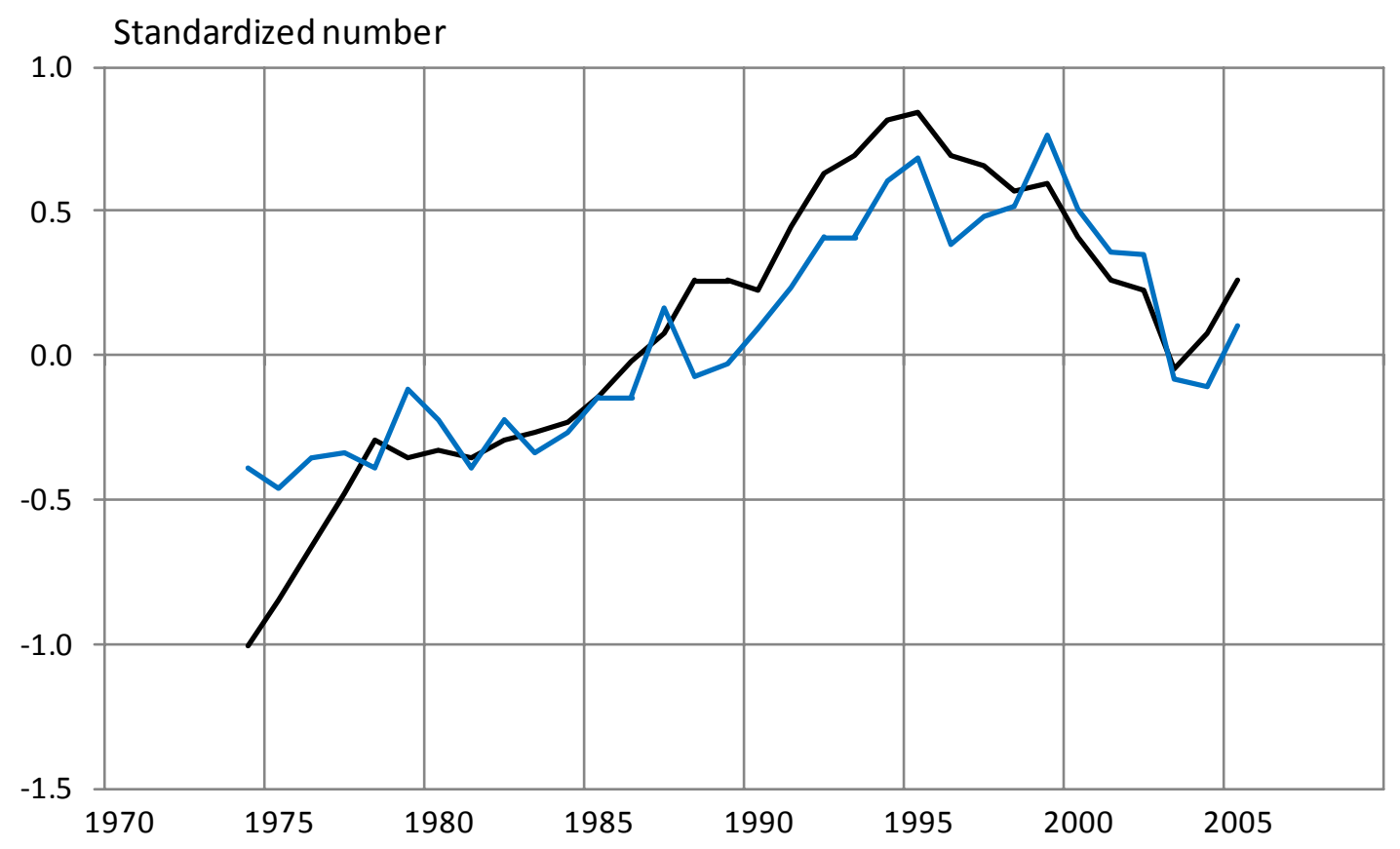

Figure 11. Nine-year running means of both the standardized annual number of direct economic normalized losses exceeding US\$ $250 \mathrm{~m}$ per event (- - , and standardized meteorological thunderstorm forcing potential caused by events exceeding a high threshold per season in the USA east of the Rocky Mountains ( - ). The meteorological measure is derived from reanalysis data and has CAPE and vertical wind shear as components. Source: Munich Re, NatCatSERVICE

\subsubsection{Climatic Impacts on Tropical Storms, Hurricanes, and Extratropical Storms}

Tropical cyclone activity is essentially determined by the warmth of the oceanic top layer as an essential energy source, atmospheric stratification and the difference in wind force and direction between lower and upper atmospheric levels, called vertical wind shear. In the past, alternating phases of relatively warm and cool average sea surface temperatures have been observed in the North Atlantic, each phase lasting for several decades. The phenomenon is known as the Atlantic Multidecadal Oscillation (AMO) (Trenberth \& Shea, 2006). Tropical cyclone activity has been considerably greater during the AMO warm phases than in the cooler period, in particular regarding intense storms (Munich Re, 2006). Currently (since 1995) a warm phase is prevailing. The El Niño/Southern Oscillation (ENSO), however, has a strong impact on the year-to-year variability of tropical cyclones. Variabilities such as the AMO and ENSO appear to be superimposed on a long-term increase in Atlantic sea surface temperatures that is most likely driven by anthropogenic climate change (Zhang \& Delworth, 2006). In the long run, tropical cyclone losses are projected to increase due to climate change. However, it might take several decades before this trend can be identified in a statistically significant way in the loss statistics.

Extratropical storm tracks from the Pacific move further south during strong El Niño phases, resulting in above-average west coast storm frequencies in California. In the case of La Niña events, the storm tracks, on average, run further north. With regard to winter storm frequency, no trend has so far emerged from 1950 onwards, neither in extratropical storms originating in the Pacific nor storms originating in the Atlantic.

\section{Conclusions}

The North American continent is unique with regard to weather risks. The continent is exposed to every type of hazardous weather peril - tropical cyclone, thunderstorm, extratropical storm, tornado, wildfire, drought and flood. In reviewing the last 30 years of activity, it is clear that the intensity and frequency of most event types is on an upward trend, ultimately leading to growing economic and insured losses. Recent events (e.g. "Frankenstorm" Sandy) have revealed the high vulnerability of certain areas and left deep holes in budgets.

In response to Hurricane Andrew, several organizations partnered with the insurance industry to develop models to assess the risk and estimate maximum losses from storm-related events. However, loss events like Hurricanes Ivan (2004), Katrina, Rita and Wilma (2005), Ike (2008) and the tornado outbreaks 2011 (including the Joplin event) 
proved that storm-related loss potential was often greater than what the models predicted. It seems we are always behind the curve, as the volatility of weather risks continues to increase and damages grow. What these models did not anticipate was socio-economic development, which is the most significant factor in large loss events. The population is growing and moving into more exposed areas like coastal regions. City boundaries are expanding, and former rural regions are becoming populated. Meanwhile, property values increase as our standard of living rises. Global warming increases the risk of severe weather and will result in loss costs from natural peril events even higher than already experienced.

What can be done about this development? An alliance between homeowners, businesses, scientists and researchers, state/provincial and federal government and the insurance industry is needed to prevent and mitigate the results of such extraordinary events. All entities need to increase their awareness and understanding of the increased risks in exposed regions and how they can adequately prepare for a catastrophe.

Risk-adequate premiums are necessary to guarantee sustainable insurability and put a price tag on risks, thus providing an incentive for protection measures. Climate-related changes in hazard are not automatically reflected in premiums. Therefore insurers must concentrate on this aspect especially. There are strong indications - in particular with respect to severe thunderstorm losses - that anthropogenic climate change is already evident from an increasing trend in normalized annual losses. We will have to monitor this development.

The insurance industry will not withdraw from business, however. It knows that wherever there are risks there are also opportunities.

\section{References}

Ashley, S. T., \& Ashley, W. S. (2008). Flood Fatalities in the United States. J. Appl. Meteor. Climatol., 47, 805-818. http://dx.doi.org/10.1175/2007JAMC1611.1

Bove, M. C. (1999). Impacts Of ENSO On United States Tornadic Activity. Center for Ocean-Atmospheric Prediction Studies (COAPS), The Florida State University, Tallahassee, FL, USA. Retrieved from https://coaps.fsu.edu/papers/impacts_enso_tornadic_activity/

Cook, A. R., \& Schaefer, J. T. (2008). The Relation of El Niño-Southern Oscillation (ENSO) to Winter Tornado Outbreaks. Monthly Weather Review, 136, 3121-3137, http://dx.doi.org/10.1175/2007MWR2171.1

Edwards, R. (2014). The Online Tornado FAQ. NOAA Storm Prediction Center. Retrieved from http://www.spc. noaa.gov/faq/tornado/index.html

Fujita, T. (2006). A Recommendation for an Enhanced Fujita Scale (EF-Scale). Wind Science and Engineering Center, Texas Tech University, Lubbock, Texas. Retrieved from http://www.spc.noaa.gov/faq/tornado/ ef-ttu.pdf

IBHS. (2012). Tornadoes: Preparedness and Strong Construction Choices Can Save Lives. Insurance Institute for Business \& Home Safety. Retrieved from http://disastersafety.org/studies-reports/ibhsdisaster-safety-review

IPCC. (2013). Climate Change 2013: The Physical Science Basis. In T. F. Stocker, D. Qin, G.-K. Plattner, M. Tignor, S. K. Allen, J. Boschung, ... P. M. Midgley (Eds.), Contribution of Working Group I to the Fifth Assessment Report of the Intergovernmental Panel on Climate Change. Cambridge University Press, Cambridge, United Kingdom and New York, NY, USA. Retrieved from http://www.ipcc.ch/report/ar5/wg1/

IPCC. (2014). Climate Change 2014: Impacts, Adaptation, and Vulnerability. Part A: Global and Sectoral Aspects. In C. B. Field, V. R. Barros, D. J. Dokken, K. J. Mach, M. D. Mastrandrea, T. E. Bilir, ... L. L. White (Eds.), Contribution of Working Group II to the Fifth Assessment Report of the Intergovernmental Panel on Climate Change. Cambridge University Press, Cambridge, United Kingdom and New York, NY, USA. Retrieved from http://ipcc-wg2.gov/AR5/report/

Kron, W. (2005). Flood Risk = Hazard · Values · Vulnerability. Water International, 30(1), 58-68. http://dx.doi. org/10.1080/02508060508691837

Munich Re. (2006). Hurricanes - More intense, more frequent, more expensive. Munich Reinsurance Company. Retrieved from http://www.climate-insurance.org/upload/pdf/MunichRe2006_Hurricanes.pdf

Munich Re. (2012). Severe weather in North America - Perils, risks, insurance. Munich Reinsurance Company. Retrieved from https://www.munichre.com/touch/naturalhazards/en/publications/weather-risks/index.html

Munich Re. (2013). Topics Geo - Natural catastrophes 2012. Munich Reinsurance Company. Retrieved from http://www.munichre.com/de/reinsurance/magazine/publications/index.html 
Sander, J., Eichner, J., Faust, E., \& Steuer, M. (2013). Rising Variability in Thunderstorm-Related U.S. Losses as a Reflection of Changes in Large-Scale Thunderstorm Forcing. Wea. Climate Soc., 5, 317-331, http://dx.doi.org/10.1175/WCAS-D-12-00023.1

Trenberth, K. E., \& Shea, D. J. (2006). Atlantic hurricanes and natural variability in 2005. Geophysical Research Letters, 33, L12704. http://dx.doi.org/10.1029/2006GL02689

Wilson, S. G., \& Fischetti, T. R. (2010). Coastline PopulationTrends in the United States: 1960 to 2008. Current Population Reports P25-1139, U.S. Department of Commerce, Economics and Statistics Administration, U.S. Census Bureau, 27 pp. (http://www.census.gov/newsroom/releases/archives/population/cb10-76.html)

Wirtz, A., Kron, W., Löw, P., \& Steuer, M. (2012). The need for data: Natural disasters and the challenges of database management. Natural Hazards. http://dx.doi.org/10.1007/s11069-12-0312-4

Zhang, R., \& Delworth, T. L. (2006). Impact of Atlantic multidecadal oscillations on India/Sahel rainfall and Atlantic hurricanes. Geophysical Research Letters, 33, L17712. http://dx.doi.org/10.1029/2006GL026267, 2006

\section{Copyrights}

Copyright for this article is retained by the author(s), with first publication rights granted to the journal.

This is an open-access article distributed under the terms and conditions of the Creative Commons Attribution license (http://creativecommons.org/licenses/by/3.0/). 